PERM JOURNAL OF PETROLEUM AND MINING ENGINEERING

ВЕСТНИК ПНИПУ. ГЕОЛОГИЯ. НЕФТЕЕАЗОВОЕ И ГОРНОЕ ДЕ

ISSN 2224-9923

Volume/ Toм 16 №2, 2017

http://vestnik.pstu.ru/geo/

УДК 622.245 .44

Article / Статья

(C) PNRPU / ПНИПУ, 2017

\title{
STUDY OF REGULARITIES ON HOW DRILLING CUTTINGS BLOCK PORES AND FRACTURES OF OIL-BEARING FORMATION
}

\section{Vasif T. Mamedov, Nigiar E. Mikailova}

Azerbaijan State Oil and Industrial University (20 Azadlyg av., Baku, AZ1010, Republic of Azerbaijan)

\section{ИССЛЕДОВАНИЕ ЗАКОНОМЕРНОСТЕЙ КОЛЬМАТАЖА ПОР И ТРЕЩИН ПОРОД НЕФТЯНОГО ПЛАСТА ШЛАМОМ ВЫБУРЕННОЙ ПОРОДЫ}

\section{В.Т. Мамедов, Н.Э. Микаилова}

Азербайджанский государственный университет нефти и промышленности (AZ1010, Азербайджан, г. Баку, пр. Азадлыг, 20)

Received / Получена: 21.01.2017. Accepted / Принята: 27.04.2017. Published / Опубликована: 30.06.2017

Key words:

oil-bearing formation, drilled cuttings, blocked layer, oil rate, drilling fluid, colmatant, drill pipes, entering, pressure drop, drilling, well, fractured rocks, liquid motion, bottomhole.

Ключевые слова нефтяной пласт, выбуренный шлам, закольматированный слой, расход нефти, промывочная жидкость, кольматант, бурильные трубы, вскрытие, перепад давления, бурение, скважина, трешиноватые породы, движение жидкости, забой.
Regularities on how drilling cuttings block pores and fractures of oil-bearing formation are studied.

There are complex physical and chemical processes at well bottomhole occur during entering oil-bearing formation by rotary or rope drilling. That is caused by quality of drilling fluid, intensity of washing, rotation of a drill string, presence of cuttings at bottomhole and a drilling technique. There are hydraulic impulse effects with alternating signs in bottomhole formation zone appear during rope drilling that have a significant impact on quality of work.

Underestimation of mentioned factors during entering oil-bearing reservoirs leads to decrease in permeability of oil rocks and well production rate.

A clear understanding of physical and chemical processes at bottomhole while entering oil-bearing reservoirs and management of these processes allow to avoid reduce in conductivity of reservoir rocks to a large extent and intensify it in some cases.

The main conditions to increase efficiency of oil wells drilling are application of such methods of entering and development of an oil-bearing reservoir that ensure preservation of its natural porosity and permeability or contribute to their increase in bottomhole part of a well.

Physical and chemical parameters of oil-bearing formation are the governing factor while choosing its entering and development technology.

In recent years, great attention has been paid to issues of entering and development oil reservoirs.

Parameters such as geological and physical properties of a reservoir, physical and chemical properties of reservoir oil, rocks and washing liquid, hydrodynamic interaction in an "oil reservoir-well" system are not considered enough in a number of cases during entering and development of a formation. That often leads to incorrect conclusions about a possibility to use actual reserves for needs of national economy.

Drilling of oil-bearing formations is a technological process, which create a bore hole in a productive oil-bearing formation for equipment of oil part of a well. Bringing a well on production include technological operations that provide installation of equipment into an oil part of a well and restoration of natural oil permeability of a formation or its artificial increase to achieve maximum production rate of a well.

Рассмотрено исследование закономерностей кольматажа пор, трещин пород нефтяного пласта шламом выбуренной породы. При вскрытии нефтяного пласта вращательным или ударно-канатным бурением на забое возникают сложные физикохимические процессы, обусловленные качеством промывочной жидкости, интенсивностью промывки, вращением колонны бурильных труб, наличием шлама на забое и технологией проводки скважины. При ударно-канатном бурении вскрытие нефтяного пласта сопровождается знакопеременными гидроимпульсными воздействиями в призабойной зоне, которые оказывают существенное влияние на качество работ.

Недооценка перечисленных факторов при вскрытии нефтяных пластов приводит в конечном счете к снижению проницаемости нефтяных пород и дебита скважины.

Четкое представление физико-химических процессов на забое при вскрытии нефтяных пластов и управление этими процессами в значительной степени позволяют избежать снижения проводимости пород пласта, а в отдельных случаях интенсифицировать ее.

Основные условия повышения эффективности бурения нефтяных скважин - это применение таких методов вскрытия и освоения нефтяного пласта, которые обеспечивают сохранение естественной его пористости и проницаемости или способствуют их увеличению в призабойной части скважины.

Решающий фактор при выборе технологии вскрытия и освоении нефтяного пласта - его физико-химические параметры. За последние годы вопросам технологии вскрытия и освоения нефтяных пластов уделяется большое внимание. В ряде случаев недостаточно учитываются геолого-физические свойства коллектора, физико-химические свойства пластовой нефти, горных пород и промывочной жидкости, гидродинамическое взаимодействие системы «нефтяной пласт скважина» в процессе вскрытия и освоения, что часто приводит к неправильным выводам о возможности использования фактических запасов нефти для нужд народного хозяйства.

Под вскрытием нефтяных пластов следует понимать технологический процесс, при котором в продуктивном нефтяном пласте образуется выработка для оборудования нефтяной части скважины. Освоение нефтяного пласта - технологические операции, обеспечивающие оборудование нефтяной части скважины и восстановление естественной нефтепроницаемости пласта или искусственное увеличение ее для достижения максимального дебита скважины.

Vasif T. Mamedov (Author ID in Scopus: 7005126723) - Doctor of Technical Sciences, Professor, Head of the Department of Oil and Gas Equipment (mob. tel.: +994 50 4127781 , e-mail: mikailova_nigar@mail.ru).

Nigiar E. Mikailova - PhD student at the Department of Oil and Gas Engineering (mob. tel.: +994 50366 49 41, e-mail: mikailova_nigar@mail.ru). The contact person for correspondence.

Мамедов Васиф Талыб оглы - доктор технических наук, профессор, заведующий кафедрой нефтяного и газового оборудования (моб. тел.: +994 504127781 , e-mail: mikailova nigar@mail.ru)

Микаилова Нигяр Энвер кызы - диссертант кафедры нефтегазовой инженерии (моб. тел.: +994 50366 49 41, e-mail: mikailova_nigar@mail.ru). Контактное лицо для переписки. 


\section{Introduction}

Quality of oil formation drilling is significantly rely on regime of slurry of cuttings.

Drilling of oil wells should be considered not only from the point of view that cuttings should be removed from the well and bottomhole should be cleaned but also from the point of view that in some cases presence of cuttings in the well is necessary. So, while drilling of oil formations composed of sands at direct circulation cuttings performs the functions of a mechanical colmatant of well walls, increasing their stability and reducing ability of a formation. Drilling of oil formations ultimately decrease permeability of oil rocks and well flow rates.

In order to avoid plugging of cracks by penetrating sludge of cuttings during the drilling of reservoirs, composed with fractured rocks, it is important to increase the size of cuttings when selecting drilling technology [1-4].

\section{Study of laws of pore colmatage}

While the drilling of oil formations composed of sands at direct circulation cuttings represent a mechanical colmatant of well walls, increasing their stability in drilling.

If mudding off of oil sands was studied in detail and its quantitative evaluation is given, then mechanical colmatage of well walls during the rotary drilling with direct circulation is not studied enough.

It is determined from the experience of oil formations drilling with direct circulation that specific absorption of oil during the drilling is in tens and hundreds times smaller than oil seepage after a well is put on production. It was also found that the higher grain size of oil sands that compose a formation, the higher specific oil absorption from 0.15 to $0.4 \mathrm{~m}^{3}$ of washing oil for $1 \mathrm{~m}$ of a drilled formation. That limited a possibility of drilling of reservoirs represented by coarse grained gravel sands at direct oil circulation.

The absence of criteria for quantitative assessment of the intensity of mechanical colmatage under various washing regimes, as well as theoretical studies in this direction were the basis for carrying out theoretical and experimental work.
Possibilities to use oil suspensions for drilling of formation with subsequent removal of a colmatage zone and restoration of natural porosity and permeability of oil rocks were studied.

An attempt was made to create a new model of mechanical colmatage by fine-sandy and dusty particles and experimental verification of theoretical positions was carried out. In development of the theory following hypotheses were adopted on the physical nature of colmatage $[1,5]$ :

1. Let assume that formation composed with watered sands, through which penetration flow goes, is represented by a set of elementary oil flow tubes with an average cross-sectional area.

2. Fluid flow carrying suspended solid sand particles is a subject to Darcy's law

$$
v=k i \text {, }
$$

where $v$ is for flow rate; $k$ is for flow coefficient; $i$ is for hydraulic gradient.

We will assume in the first step that solid particles of suspension have the same diameter $D$, and a cross section of an elementary oil flow tube before the beginning of colmatage varies along the length of flow path from the maximum pore diameter $d_{\max }$ to the minimum $d_{\min }$. Let diameter of colmatant be such that in oil tubes there are critical cross sections for which $d$ $<D$. Having critical cross section reached a particle gets stuck and all the particles moving after it settle in an oil flow pipe $[2,6,7]$.

Let $s$ be the length of free path of a particle along the oil flow tube to a critical value. Obviously, $s$ is a random variable. Let $\xi$ be an arbitrary distance along an oil flow tube. Obviously, the probability that a tube will be blocked on the section $\Delta \xi$, will be proportional to $\Delta \xi$ with accuracy of infinite small of higher order.

Then, using apparatus of the probability theory, probability distribution laws are easily obtained with assumed schematization of the process of colmatage $P(\xi)$ and $Q(\xi), p(\xi)=e^{e \lambda \xi}, Q(\xi)=1-e^{-\lambda \xi}$.

In given expressions $Q(\xi)$ is the law of probability distribution $p(s<\xi)$, where $p(\xi)-p(s>\xi)$. During derivation $\lambda=$ const, which is valid because of initial homogeneity of 
porous medium. In a general case $\lambda$ is a function of $s$ coordinate. Then we have $p(\xi)=e^{-\int_{0}^{-\xi_{\lambda}(\xi) d(\xi)}}$.

In case at the end of the colmatage process a sufficiently large value of flow that contain a plurality of elementary oil pipe tubes is taken, then, according to the law of large numbers, the probability $P(\xi)$ in a cross section with coordinate $\xi$ determines a relative number of blocked oil flow pipes [8-9].

Let $k_{0}$ and $k_{1}$ be flow coefficients in unblocked and blocked parts of a cross section. Then an average flow coefficient for the entire cross section will be

$$
k(\xi)=k_{0}\left[1-e^{\lambda \xi}\right]+k_{1} e^{-\lambda \xi} .
$$

In this equation $k_{1}$ is a variable value characterizing change in flow coefficient over the time and in a constant section of sands to be blocked.

An exponential law of probability distribution is also relevant to describe a process of blockage in time in a section with a constant coordinate $p(t)=e^{-\delta t}, Q(t)=1-e^{\delta t}$.

Then an average value of flow coefficient of upper layer at an arbitrary time can be represented as

$$
k_{1}(t, \xi=0)=k_{0} e^{-\delta t}+k_{2}\left(1-e^{-\delta t}\right),
$$

where $k_{2}$ is a flow coefficient at the end of blockage process under given conditions. From this we derive

$$
k(\xi t)=\left(1-e^{-\lambda \xi}\right)+k_{0} e^{\delta t}+k_{2}\left(1-e^{\delta t}\right) e^{-\lambda \xi},
$$

where $\lambda$ and $\delta$ are parameters determined experimentally.

The obtained theoretical functions were verified in laboratory conditions on a simple pilot installation with flat filtration (Fig. 1). Separate sand fractions corresponding to the main varieties ranging from shallow to gravel were studied.

To measure hydraulic heads along the length of flow path, a series of inclined piezometers were installed in constant cross sections of oil sand to be colmatized. Experiments were carried out on compacted samples. Flow was carried out from a pressure tank filled with a blocking suspension [10-12].

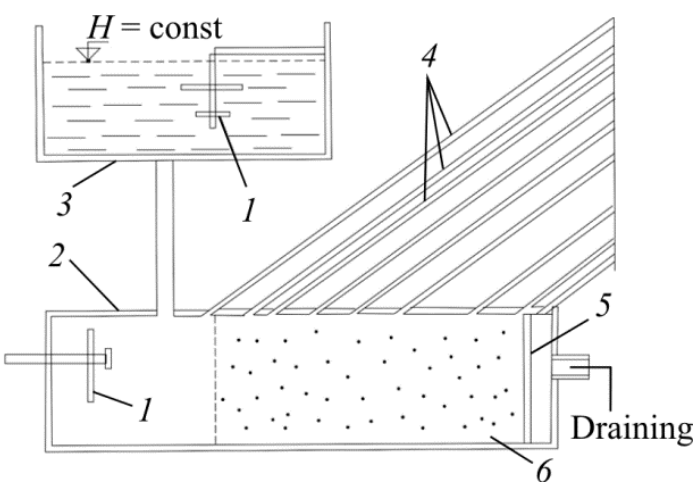

Fig. 1. Scheme of the installation to study mechanical colmatage: 1 - mixer; 2 - body made of organic glass;

3 - oil tank with blocking; 4 - inclined piezometers;

5 - anti-suffusion filter; 6 - soil to be blocked

In order to prevent settling of the suspension, two mixers were installed that mix suspension continuously. In addition to hydraulic heads, flow rate of flowing slurry was measured in various sections of samples. Flowed oil was collected into a graduated cylinder where concentration of a suspension was determined at the inlet and outlet of an installation.

For blockage suspensions of various concentrations with different fineness of blocking grains were used. In addition, in separate series of experiments, initial hydraulic head was changed. For all types of sands, a critical gradient was determined both in absence and presence of a blocked layer. The process of collapse of a sand wall with a decrease in difference in pressure was recorded on a film stock.

Experimental values of flow coefficients in different cross sections of samples were determined using Darcy's law. Fig. 2 and 3 represent comparison of flow coefficients calculated by formulas (2) and (3) with their experimental values.

It can be seen in Fig. 2 and 3 that the proposed theoretical functions agree with experimental data.

Blocking is appear to be most rapid in time at minimum penetration depth of suspension particles into oil sands that are under study at optimal ratios of the indicated diameters. For all studied sand fractions (from dust to gravels), the optimal ratios of $d_{k} / d_{p}$ are 0.1 .

These results of research are of great practical importance. 


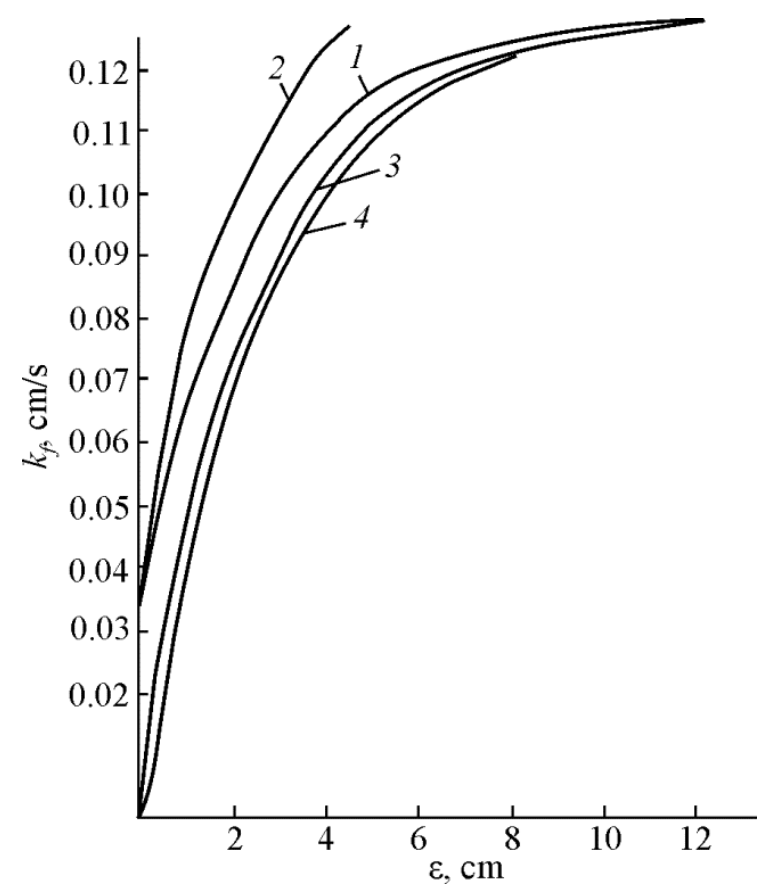

Fig. 2. Graph of change in the coefficient of flow along the length at various times (sand fractions is $0.25-0.5 \mathrm{~mm}$, colmatant fraction $0.01-0.05 \mathrm{~mm}$, concentration is $3.9 \mathrm{~g} / 1$, $\left.k_{0}=0.1259 \mathrm{~cm} / \mathrm{s}, \delta=1.3, \lambda=0.4\right): 1$ - theoretical curve; 2 - experimental curve for $t=1 \mathrm{~min} ; 3$ - same for $t=2$ $\min$; 4 - same for $t=10 \mathrm{~min}$

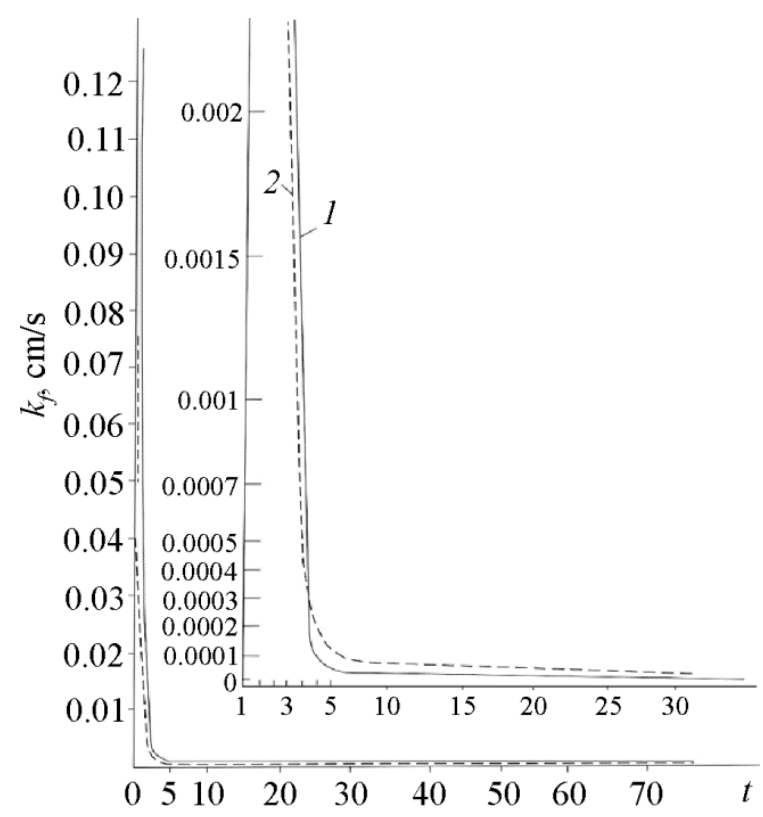

Fig. 3. Graph of change in the coefficient of flow in time (sand fraction is $0.25-0.5 \mathrm{~mm}$, colmatant fraction is $0.01-0.05 \mathrm{~mm}$, concentration is $3.9 \mathrm{~g} / 1, k=0.1259 \mathrm{~cm} / \mathrm{s}$, $\left.K_{\mathrm{K}}=0.0003 \mathrm{~cm} / \mathrm{s}, \delta=1.3, \xi=0\right): 1-$ theoretical curve; 2 - experimental curve
Colmatage of a near walls massif, drilled by a well of an oil reservoir, plays an important role in assessing the stability of walls of a well and reducing specific oil absorption during formation drilling. The performed researches allow to make a quantitative estimation [13-15]: size of sand fraction $(\mathrm{mm})$ is $2-5 ; 1-2 ; 0.5-1 ; 0.25-0.5 ; 1.1-0.25$; optimal size of the colmatant $(\mathrm{mm})$ is $0.2-0.5$; $0.1-0.2 ; 0.05-0.1 ; 0.01-0.05 ; 0.005-0.01$.

Critical excessive hydrostatic head $\Delta H_{\text {cr }}$ to support the wall of the well in a stable state with considered colmatage is determined by the formula

$$
\Delta H_{\mathrm{cr}}=\frac{\gamma_{0} k_{1} r_{0} \ln \frac{r_{2}}{r_{0}}}{\rho e \operatorname{tg} \varphi k_{\text {equiv }}},
$$

where $\gamma_{0}$ is bulk density of rocks; $k_{1}$ is coefficient of flow at the end of colmatage; $r_{0}$ is well radius; $r_{2}$ is radius of well influence; $\rho$ is water density; $e$ is rock porosity; $\varphi$ is angle of internal friction of waterbearing sands; $k_{\text {equiv }}$ is equivalent flow factor.

Oil consumption required to ensure stability of well walls during drilling of oil sands using direct mud circulation, taking into account colmatage, will be determined by the formula

$$
Q_{c r}=\frac{\gamma_{0} 2 \pi h k_{1} r_{0}}{\rho e t g \varphi},
$$

where $h$ is thickness of drilled formation.

If there is no colmatage oil consumption can be calculated by formula

$$
Q=\frac{2 h \pi k_{0} \Delta H_{c r}}{\ln \frac{r_{2}}{r_{0}}} .
$$

It is easy to see that required oil consumption and excessive hydrostatic heads in presence of blocking matter and optimal blocking regime are reduced by a factor of hundreds in comparison with corresponding values if there is no blockage. That is confirmed in practice [16-19].

\section{Drilling of oil-bearing formations by a slurry of cuttings}

Thus, based on study of influence of blockage on stability of walls of wells, it can be concluded 
that it is possible to expand the field of application of drilling of oil-bearing formations with direct oil circulation up to gravel sands and gravel. It is possible if appropriate technology of drilling is developed. Laboratory experiments have shown that stability of vertical walls of wells in gravel sand and gravel sediments in presence of blockage can be ensured with minimal consumption of technical oil for washing during formation drilling [2].

As a result of rotation of a drill string in a well filled with oil turbulence is established. Calculation data show that drilling with oil circulation (kinetic viscosity $v$ of $0.01 \mathrm{~m}^{2} / \mathrm{s}$ ) in case of a drill string with a diameter of $73 \mathrm{~mm}$ with rotational speed $\approx 100 \mathrm{rpm} R_{e}=\omega r^{2} / v \approx 2,1 \cdot 10^{3}$.

Rotation speed of a fluid is proportional to peripheral speed of drilling tool. In this case resulting speed $\omega$ will be equal to geometric sum of speeds such as circle $v_{\text {periph }}$ and translational $c$, directed vertically, $\omega=\sqrt{v_{\text {periph }}^{2}+c^{2}}$.

Such resultant velocity will be directed along the helix with an angle of ascent that depends on given speeds. Thus, resulting velocity $\omega$ will be always greater than $c$, i.e. the higher the rotational speed of a drilling tool the cleaner will be bottomhole with other things being equal.

Depending on rotation of a drill string peripheral speed of circulation liquid movement $v_{\text {periph }}$ is determined by the expression $v_{\text {periph }} \approx 28(V / S)^{1 / 3}$ where $V$ is volume of a particle; $S$ is its area.

At the moment when penetration into formation by rotation of a drill string begins it is recommended to increase calculated size of removed cuttings in 2-3 times, i.e. $l_{\text {exper }} / l_{\text {theor }}=2 / 3\left(l_{\text {exper }}\right)$ is the size of cuttings taken out from the well at the moment of penetration into formation with rotation of a drill shaft; $l_{\text {theor }}$ is the theoretical (critical) size of cuttings, calculated by formulas for conditions of rectilinear motion of a circulation fluid. The effect of flow forces on cutting, that is caused by absorption of circulationg fluid by a formation, is not taken into account [20-22].

Thus, it is obvious that each particle of cuttings (drilled sand) during the drilling of an oil reservoir moves upwards and is influenced by forces that are as follows: lift of upward flow of water in the well, inertial (caused by twisting of flow by a rotating drill string), flow (from absorption of circulating oil by a formation during its penetration).

Speed of oil flow into a not blocked yet formation at the moment of opening is very significant and can be determined by expression

$$
u_{f}=Q_{o} / 2 \pi r \ln
$$

where $Q_{o}$ is pump rate; $r$ is well radius at the formation interval; $l$ is length of intensive absorption section; $n$ is active porosity of oil rocks.

Penetration flow has a significant effect on a particle of a slurry (sand) located at the bottomhole in the absorption interval. In this case hydrodynamic pressure of flow on a particle of sand during infiltration can be determined by the expression

$$
p=c \frac{\pi d_{p}^{2}}{4} \frac{u_{f}^{2}}{2 g} \rho_{2},
$$

where $c$ is coefficient of frontal resistance (hydrodynamic characteristic), is considered for turbulent flow in a well; $d_{f}$ is nominal diameter of a particle of cuttings (sand); $u_{f}$ is speed of flow in an absorption interval; $g$ is acceleration of gravity; $\rho_{2}$ is density of an oil flow in a well.

Quite complex movement of a particle of sludge (sand) in oil flow during formation penetration leads to stratification of slurry according with grain size in a plane perpendicular to a well axis. As a result of flow turbulence, the lowest speed of its movement is near the well wall, where small particles of sand move. Obviously, these particles are picked up by flow of oil that infiltrate into a reservoir. Then under the influence of hydrodynamic forces and frictional forces caused by flow pressure, they block pores and channels of a porous reservoir that minimizes its ability to absorb oil and increase its stability of well walls against caving [23].

Thus, total force acting on a particle of sludge (sand) in turbulent flow at an absorption interval of a formation is a vector quantity and depends on many factors.

While drilling of oil reservoirs, which are represented by naturally fractured rocks, removed cuttings and circulation fluid penetrate into cracks. 
A fluid together with spherical body moves in a horizontal crack. There are four forces applied on a spherical body such as body weight $G$ directed downwards, pressure $p$ equal to weight displaced by a fluid body and directed upwards, active pressure $X$ of fluid jet on a body directed towards fluid motion, a force of resistance of body $N$ to movement caused by friction of a particle on a channel surface and directed backwards to fluid flow.

Weight of a spherical particle expressed in terms of volume, $G=\frac{\pi \delta^{3}}{6} \gamma$ where $\delta$ is particle diameter; $\gamma$ is its specific weight. Pressure $p=\frac{\pi \delta^{3}}{6} \gamma_{1}$, where $\gamma_{1}$ is fluid specific gravity.

Active flow pressure acting on a particle is given by expression

$$
X=c F \frac{u^{2}}{2 g},
$$

where $c$ is a coefficient depending on shape of a body, its size and Reynold's number; $F$ is an area of resistance of a body; $u$ is velocity of motion of a liquid; $g$ is acceleration of gravity.

Force of resistance to movement

$$
N=\frac{\pi \delta^{3}}{6}\left(\gamma-\gamma_{1}\right) f,
$$

where $f$ is friction coefficient.

From equilibrium condition $X$ and $N$ are equal and expressions are solved with respect to speed velocity of a fluid $u$. Taking into account $F=\pi \delta^{2} / 4$, following is obtained

$$
u=\sqrt{\frac{\delta\left(\gamma-\gamma_{1}\right)}{\gamma_{1}} \sqrt{4 g / 3 c} \sqrt{f}} .
$$

The first two numbers in this expression represent Retinger formula, in which a term $\sqrt{4 g / c}$ is expressed in terms of coefficient $k$.

If Reynolds number $\mathrm{Re}>1000$, coefficient $k$ becomes constant and depends only on shape of streamlined bodies.

Thus, the critical speed of a sludge particle in a horizontal crack can be written as formula

$$
u=k \sqrt{\frac{\delta\left(\gamma-\gamma_{1}\right)}{\gamma_{1}}} \sqrt{f}
$$

Speed of fluid movement in a formation at distance $R$ from a well axis under a condition of uniform fracturing and constant absorption of $Q$ can be expressed as

$$
v=\frac{Q}{2 \pi R n_{a} m},
$$

where $n_{a}$ is active fracturing coefficient; $m$ is interval absorption thickness.

Equating speeds $u$ and $v$ and solving the equation with respect to $R$, the authors obtained a formula to find possible magnitude of displacement of a particle in a horizontal crack at a specific diameter $\delta$ and constant absorption

$$
R=\frac{Q}{2 \pi n_{a} m k \sqrt{\frac{\delta\left(\gamma-\gamma_{1}\right)}{\gamma_{1}}}} .
$$

For an inclined crack the formula will be

$$
R=\frac{Q}{2 \pi n_{a} m k \sqrt{\frac{\delta\left(\gamma-\gamma_{1}\right)}{\gamma_{1}}(f \cos \alpha \pm \sin \alpha)}},
$$

where $\alpha$ is an angle of inclination of a crack to the horizon (plus sign characterizes rise cracks, negative sign characterises descending ones).

However, consumption of fluid during absorption in a general case does not remain constant and can vary depending on pressure drop, time and is determined by the formula

$$
Q=\frac{4 k_{f} m\left(p-p_{r e s}\right)}{\ln \frac{2,25 a t}{r_{0}^{2}}}
$$

where $k_{f}$ is a penetration coefficient; $p$ is hydrostatic pressure in the well; $p_{\text {res }}$ is reservoir pressure; $a$ is piezoelectric conductivity; $r_{0}$ is well radius; $t$ is time.

Replacing flow $Q$ in formula (12) through its value, determined by formula (13), we finally obtain

$$
R=\frac{2 k_{0} k_{f}\left(p-p_{\text {res }}\right)}{n_{a} k \sqrt{\frac{\delta\left(\gamma-\gamma_{1}\right)}{\gamma_{1}}(f \cos \alpha \pm \sin \alpha) \ln \frac{2,25 a t}{r_{0}^{2}}}},
$$


where $k_{0}$ is a dimensionless coefficient that takes into account ratio of size of sludge particles and a crack channel.

It can be seen from formula (14) that sludging radius is directly proportional to pressure of a formation liquid. In accordance to that, drilling of naturally fractured oil reservoirs should be usually performed with air blowing or using aerated circulation liquids. In addition, increase in intensity of blowing (washing) is a reliable method against crack sludging that ensures removal of large cuttings out of bottomhole.

Presence of cuttings in a fluid that fills a well reduces acceleration of free fall of a drilling tool:

$$
a_{1}=\frac{d v}{d t}=k g \frac{\gamma L 2 \gamma_{c u t} l_{c u t}}{\gamma l+\gamma_{c u t} l_{c u t} \frac{l^{2}}{1-l^{2}}},
$$

where $\gamma$ is specific weight of steel; $\gamma_{c u t}$ is specific weight of cuttings; $L$ is height of percussion instrument; $l_{\text {cut }}$ is height of margin of cutting; $l$ is height of tool lifting above a bottomhole $\left(l=d_{T} / d\right.$, $d_{T}$ is diameter of percussion instrument; $d$ is diameter of borehole).

Calculations show that acceleration of free fall of a drilling tool $a_{1}$ depending on regime of cutting flow varies between 5.5 and $6.5 \mathrm{~m} / \mathrm{s}^{2}$.

Speed of movement of fluid and cuttings together and in annular space between well walls and a tool taking into account continuity condition of flow is given by

$$
u=v\left(1 / l^{2}-1\right) .
$$

Thus, kinetic energy of a whole system, i.e. sludged circulation fluid and drilling tools represent the sum of energies

$$
\Sigma W_{k}=k \frac{m v^{2}}{2 g}+\frac{G u^{2}}{2 g},
$$

where $G$ is weight of column of cuttings.

Run-in-hole and pull-out-of-hole operations in a well are followed by wave processes. There is an overpressure of 4-5 MPa at $1000 \mathrm{~m}$ in a cased well during drillstring run-in-hole operations and pressure drop of 1.0-1.2 $\mathrm{MPa}$ during pull-out-ofhole operations. For an open hole in unconsolidated deposits filled with a clay solution overpressure may be greater than above mentioned. A pressure fluctuation during run-inhole and pull-out-of-hole operations increases with increase in viscosity of circulation fluid. That is also caused by formation of seals during drilling of sandy-argillaceous sections [24-25].

In order to determine hydrodynamic pressure necessary to overcome the inertia of a drilling during run-in-hole of drilling tool following formula is proposed:

$$
\Delta p_{R H}=\frac{0,11 g \gamma l}{\left(\frac{d_{2}}{d_{T}^{2}}\right) T^{0,47}},
$$

where $\gamma$ is specific gravity of washing liquid, $\mathrm{kN} / \mathrm{m}^{3} ; l$ is well depth, $\mathrm{m} ; d$ and $d_{T}$ are diameters of a well and drilling tool, $\mathrm{m} ; T$ is time counted from the beginning of run-in-hole of a candle, $s$.

Calculations performed by this formula show that $+\Delta p_{R H}$ often exceeds pressure of reservoir fracturing, which results in collapse of well walls.

There are dynamic impulse processes generated in the well during well flushing of rotary drilling by piston pumps whose operation is characterized by a pulsating regime. Pumping out of matter from wells was done by jet pumps driven by piston drilling pumps. Observation of that pumping allowed to determine that pulsation frequency in a well corresponds to a number of double strokes of a piston pump. Magnitude of pulses of hydrodynamic pressure excited in a well has a $0.2-0.3 \mathrm{MPa}$ at a vibration frequency of 7592 per $1 \mathrm{~min}$.

It is clear that hydrodynamic pulsation in a well will also occur with water jet bits being at work [26].

\section{Conclusion}

Derived function allows to determine a zone of sludging taking into account a large number of factors, both technical and hydrodynamic, and can be used to assess effectiveness of a technology of drilling of oil reservoirs in fractured rocks.

Information given above proves that radius of sludging is directly proportional to fluid pressure on a formation. In accordance with this, drilling of 
oil reservoirs with fractured reservoirs should, as a rule, be carried out with air blowing or using aerated circulating fluids. Besides, a reliable method of sludging control is to increase intensity of blowing (circulation), which ensures removal of larger cuttings from a bottomhole.

\section{References}

1. Iasashin A.M. Vskrytie oprobovaniia i ispytaniia skvazhin [Opening and testing of wells]. Moscow, Nedra, $1979,264 \mathrm{p}$

2. Mamedov V.T., Mikailova N.E. Opredelenie sily podavaemoi na paker pri ekspluatatsii fontannykh skvazhin [Determination of the force applied to the packer during operation of the fountain wells]. Izvestiia Vysshikh tekhnicheskikh uchebnykh zavedenii Azerbaidzhana, 2015, no.4 (98).

3. Mirzadzhanzade A.Kh., Ametov I.M., Khasaev A.M., Gusev V.N. Tekhnologiia i tekhnika dobychi nefti [Technology and technology of oil production]. Moscow, Nedra, 1986, $382 \mathrm{p}$.

4. Varlamov P.S. Ispytanie plastov mnogotsiklovogo deistviia [Testing of multi-cycle actions]. Moscow, Nedra, 1982, $247 \mathrm{p}$.

5. Basarygin Iu.M., Bulatov A.I., Proselkov Iu.M. Burenie neftianykh i gazovykh skvazhin [Drilling of oil and gas wells]. Moscow, Nedra-Biznestsentr, 2002, 632 p.

6. Maksimov V.P. Ekspluatatsiia neftianykh mestorozhdenii v oslozhnennykh usloviiakh [Operation of oil fields in complicated conditions]. Moscow, Nedra, 1976, $239 \mathrm{p}$.

7. Chernyi I.A. Neustanovivsheesia dvizhenie real'noi zhidkosti $\mathrm{v}$ trubakh [Unsteady motion of a real liquid in pipes]. Moscow, Nedra, 1975, $296 \mathrm{p}$.

8. Avrushenko V.Kh. Rezinovye uplotniteli [Rubber seals]. Leningrad, Khimiia, 1978, 136 p.

9. Litvinov V.M. K voprosu o deformirovaniia uplotnitel'nykh manzhet [On the question of deformation of the sealing cuffs]. RNTS VNIIOENG. Seriia: Mashiny $i$ neftianoe oborudovanie, 1965, no.5, pp.18-21.

10. Mikailova N.E. Opredelenie sily, trebuemoi dlia uplotneniia mezhtrubnogo prostranstva na skvazhinakh [Determination of the force required to compact the annular space in the wells]. Teoreticheskaia i prikladnaia mekhanika, 2015, no.2(38), pp.24-28.

11. Katalog kompanii Maritime Hydraulics [Companies catalog Maritime Hydraulics]. The University of Alaska Fairbanks, 1998-1999.

12. Composite catalog of Oil Field Equipment and Services. Texas, USA, World Oil A Gulf Publishing Company Publication, 1979-1981.

13. Suleimanov A.B. et al. Ekspluatatsiia morskikh neftegazovykh mestorozhdenii [Exploitation of offshore oil and gas fields]. Moscow, Nedra, 1986, 285 p.

14. Agarwal R.G., Al-Hussainy R., Ramey H.J. An investigation of wellbore storage and skin effect in unsteady liquid flow: I. Analytical Treatment, Society of Petroleum Engineers Journal, 1970, vol.10, iss.03, pp.279-290. DOI: $10.2118 / 2466-P A$

15. Kohlhaas C.A. A method for analyzing pressures measured during drillstem-test flow periods. Journal of Petroleum Technology, 1972, vol.24, iss.10, pp.12781282. DOI: $10.2118 / 3695-P A$

16. Ramey H.J. Short-time well test data interpretation in the presence of skin effect and wellbore storage. Journal of Petroleum Technology, 1970, vol.22, iss.01, pp.97-104. DOI: 10.2118/2336-PA

17. Kachanov L.M. Osnovy teorii plastichnosti [Fundamentals of the theory of plasticity]. Moscow, Nauka, 1969, $420 \mathrm{p}$.

18. Kvashnin G.P. Tekhnologiia vskrytiia i osvoeniia vodonosnykh plastov [Technology of opening and development of aquifers]. Moscow, Nedra, 1987, 247 p.

19. Gaivoronskii A.A., Tsybin A.A. Kreplenie skvazhin i razobshchenie plastov [Well fixing and seam separation]. Moscow, Nedra, 1981, 387 p.

20. Shakirov A.F., Belov A.E., Riazantsev N.F. $\mathrm{O}$ rezhimakh ispytaniia ob"ektov $\mathrm{v}$ buriashchikhsia skvazhinakh [About modes of testing objects in drilled wells]. Neftianoe khoziaistvo, 1973, no.6, pp.14-17.

21. Il'skii A.L., Shmidt A.P. Burovye mashiny i mekhanizmy [Drilling machines and mechanisms]. Moscow, Nedra, 1989, 396 p.

22. Severinchik N.A. Mashiny i oborudovanie dlia bureniia skvazhin [Machines and equipment for drilling wells]. Moscow, Nedra, 1986, 386 p.

23. Skrypnik S.G. Tekhnika dlia bureniia neftianykh i gazovykh skvazhin na more [Equipment for drilling oil and gas wells at sea]. Moscow, Nedra, 1989, $310 \mathrm{p}$.

24. Vervekin A.V. To the question of automation of oil and gas wells drilling with screw downhole motors. Bulletin of Perm National Research Polytechnic University. Geology. Oil \& Gas Engineering \& Mining, 2014, no.10, pp.49-65. DOI: $10.15593 / 2224-9923 / 2014.10 .5$

25. Lyons $\mathrm{C}$. Working guide to drilling equipment and operations. Houston, Gulf Publishing, 2010, p.617.

26. Mikailova N.E. Opredelenie ekspluatatsionnoi kharakteristiki pakerov pri razlichnykh sposobakh osvoeniia neftianykh plastov [Determination of the performance of packers for various methods of developing oil reservoirs]. Stroitel'stvo neftianykh i gazovykh skvazhin na sushe i na more, 2015, no.10, pp.23-25. 


\section{Библиографический список}

1. Ясашин А.М. Вскрытие опробования и испытания скважин. - М.: Недра, 1979. - 264 с.

2. Мамедов В.Т., Микаилова Н.Э. Определение силы, подаваемой на пакер, при эксплуатации фонтанных скважин // Известия высших технических учебных заведений Азербайджана. - 2015. - № 4 (98). - С. 52-55.

3. Технология и техника добычи нефти: учеб. для вузов / А.Х. Мирзаджанзаде, И.М. Аметов, А.М. Хасаев, В.Н. Гусев. - М.: Недра, 1986. - 382 с.

4. Варламов П.С. Испытание пластов многоциклового действия. - М.: Недра, 1982. - 247 с.

5. Басарыгин Ю.М., Булатов А.И., Проселков Ю.М. Бурение нефтяных и газовых скважин: учеб. пособие для вузов. - М.: Недра-Бизнесцентр, 2002. - 632 с.

6. Максимов В.П. Эксплуатация нефтяных месторождений в осложненных условиях. - М.: Недра, 1976. - 239 с.

7. Черный И.А. Неустановившееся движение реальной жидкости в трубах. - М.: Недра, 1975. - 296 с.

8. Аврушенко В.Х. Резиновые уплотнители. - Л.: Химия, 1978. - $136 \mathrm{c.}$

9. Литвинов В.М. К вопросу о деформировании уплотнительных манжет // РНТС ВНИИОЭНГ. Серия: Машины и нефтяное оборудование. - 1965. - № 5. - С. 18-21.

10. Микаилова Н.Э. Определение силы, требуемой для уплотнения межтрубного пространства на скважинах // Теоретическая и прикладная механика. 2015. - № 2 (38). - C. 24-28.

11. Каталог компаний Maritime Hydraulics / The University of Alaska Fairbanks, 1998-1999.

12. Composite catalog of Oil Field Equipment and Services. Texas, USA, World Oil A Gulf Publishing Company Publication, 1979-1981.

13. Эксплуатация морских нефтегазовых месторождений / А.Б. Сулейманов [и др.]. - М.: Недра, 1986. -285 c.

14. Agarwal R.G., Al-Hussainy R., Ramey H.J. An investigation of wellbore storage and skin effect in unsteady liquid flow. I // Analytical Treatment, Society of
Petroleum Engineers Journal. - 1970. - Vol. 10, iss. 03. P. 279-290. DOI: 10.2118/2466-PA

15. Kohlhaas C.A. A method for analyzing pressures measured during drillstem-test flow periods // Journal of Petroleum Technology. - 1972. - Vol. 24, iss. 10. P. 1278-1282. DOI: $10.2118 / 3695-P A$

16. Ramey H.J. Short-time well test data interpretation in the presence of skin effect and wellbore storage // Journal of Petroleum Technology. - 1970. - Vol. 22, iss. 1. - P. 97-104. DOI: 10.2118/2336-PA

17. Качанов Л.М. Основы теории пластичности. М.: Наука, 1969. - 420 с.

18. Квашнин Г.П. Технология вскрытия и освоения водоносных пластов. - М.: Недра, 1987. - 247 с.

19. Гайворонский А.А., Цыбин А.А. Крепление скважин и разобщение пластов. - М.: Недра, 1981. - 387 с.

20. Шакиров А.Ф., Белов А.Е., Рязанцев Н.Ф. О режимах испытания объектов в бурящихся скважинах // Нефтяное хозяйство. - 1973. - № 6. - С. 14-17.

21. Ильский А.Л., Шмидт А.П. Буровые машины и механизмы. - М.: Недра, 1989. - 396 с.

22. Северинчик Н.А. Машины и оборудование для бурения скважин. - М.: Недра, 1986. - 386 с.

23. Скрыпник С.Г. Техника для бурения нефтяных и газовых скважин на море. - М.: Недра, 1989. -310 с.

24. Вервекин А.В. К вопросу автоматизации процесса бурения нефтяных и газовых скважин винтовыми забойными двигателями // Вестник Пермского национального исследовательского политехнического университета. Геология. Нефтегазовое и горное дело. - 2014. - № 10. - С. 49-65. DOI: $10.15593 / 2224-9923 / 2014.10 .5$

25. Lyons C. Working guide to drilling equipment and operations. - Houston: Gulf Publishing, 2010. - P. 617.

26. Микаилова Н.Э. Определение эксплуатационной характеристики пакеров при различных способах освоения нефтяных пластов // Строительство нефтяных и газовых скважин на суше и на море. -2015 . - № 10. - С. $23-25$.

Please cite this article in English as:

Mamedov V.T., Mikailova N.E. Study of regularities on how drilling cuttings block pores and fractures of oil-bearing formation. Perm Journal of Petroleum and Mining Engineering, 2017, vol.16, no.2, pp.129-137. DOI: 10.15593/2224-9923/2017.2.3

Просьба ссылаться на эту статью в русскоязычных источниках следующим образом:

Мамедов В.Т., Микаилова Н.Э. Исследование закономерностей кольматажа пор и трещин пород нефтяного пласта шламом выбуренной породы // Вестник Пермского национального исследовательского политехнического университета. Геология. Нефтегазовое и горное дело. - 2017. - Т.16, №2. - C.129-137. DOI: 10.15593/2224-9923/2017.2.3 